\title{
MENINGKATKAN HASIL BELAJAR MATEMATIKA PADA MATERI OPERASI HITUNG PENJUMLAHAN PECAHAN DENGAN PENDEKATAN CTL (CONTEXTUAL TEACHING AND LEARNING)
}

\author{
Kirana Chityadewi \\ UPGRIS (Universitas PGRI Semarang) \\ kirana.chityadewi@gmail.com
}

\begin{abstract}
Abstrak
Tujuan dari penelitian ini yaitu: 1) Untuk meningkatkan hasil belajar matematika pada operasi hitung penjumlahan pecahan bagi siswa Kelas IV SD Negeri Wedarijaksa 01. 2).Untuk mengetahui bagaimana pendekatan CTL (contextual teaching and learning dapat meningkatkan pembelajaran matematika materi operasi hitung penjumlahan pecahan. Penelitian tindakan kelas ini menggunakan subyek dan setting penelitian kelas IV semester II Tahun Pelajaran 2018/2019 SD Negeri Wedarijaksa 01 Kecamatan Wedarijaksa Kabupaten Pati. Penelitian ini dilaksanakan dalam 2 siklus tindakan dalam rangka meningkatkan hasil belajar pada operasi hitung penjumlahan pecahan. Berdasarkan analisis hasil observasi selama 2 siklus tindakan dan pembahasan, dapat disimpulkan bahwa: 1) Dengan penggunaan pendekatan CTL (contextual teaching and learning, hasil pembelajaran matematika pada operasi hitung penjumlahan pecahan mengalami peningkatan baik secara kuantitas maupun kualitas, 2) Teknik pembelajaran ini sesuai dengan cara pembelajaran yang diinginkan oleh siswa, 3) Model pembelajaran ini sesuai suasana pembelajaran yang mandiri merangsang daya kreatifitas dan keaktivan siswa karena dapat menghubungkan pembelajaran dengan alam sekitar.
\end{abstract}

Kata Kunci: Hasil Belajar,Operasi Hitung, Pecahan, CTL (Contextual Teaching and Learning)

\begin{abstract}
The purpose of this study are: 1) To improve mathematics learning outcomes in fraction summing operations for Fourth Grade students of SD Negeri Wedarijaksa 01. 2). To find out how the CTL (contextual teaching and learning approach) can improve mathematics learning in fraction sum operations. This class action research uses subjects and fourth grade research settings in the second semester of 2018/2019 Academic Year SD Negeri Wedarijaksa 01 Kecamatan Wedarijaksa Kabupaten Pati This research was conducted in 2 cycles of action in order to improve learning outcomes in calculating fraction addition operations. 2 cycles of action and discussion, it can be concluded that: 1) With the use of the CTL (contextual teaching and learning approach), mathematics learning outcomes in fraction addition operations have increased both in quantity and quality, 2) This learning technique is appropriate learning outcomes desired by students, 3) This learning model suits an independent learning atmosphere which stimulates student creativity and activity because it can connect learning with the natural surroundings.
\end{abstract}

Keywords: Learning Outcomes, Count Operations, Fractions, CTL (Contextual Teaching and Learning

\section{Pendahuluan}

Dalam proses belajar matematika, ada kegiatan utama yaitu belajar bagi peserta didik dan mengajar oleh guru. Peserta didik belajar karena ingin mencapai hasil atau nilai yang baik, sedangkan guru mengajar karena ingin melihat peserta didik itu memperoleh hasil belajar yang lebih baik. Belajar adalah sebuah proses perubahan didalam kepribadian manusia dan perubahan tersebut ditampakkan dalam bentuk peningkatan kualitas dan kuantitas tingkah laku seperti peningkatan kecakapan, pengetahuan, sikap, kebiasaan, pemahaman, ketrampilan, daya pikir, dan kemampuan yang lain. Menurut Sam's (2010:31) Pengertian belajar adalah perubahan kemampuan dan disposisi seseorang yang dapat dipertahankan dalam suatu periode teretentu dan bukan merupakan hasil proses pertumbuhan. Belajar adalah merupakan sebuah proses yang kompleks yang terjadi pada semua orang dan berlangsung seumur hidup, sejak masih bayi (bahkan dalam kandungan) hingga liang lahat. (Nara, Hartini dan Siregar 2014 : 1). Manfaat belajar dalam pembelajaran yaitu mengolah fungsi otak sehingga tidak beku agar terhindar dari kebodohan, rajin belajar membuat pintar karena dalam belajar kita mendapatkan wawasan yang luas supaya tidak tertinggal oleh IPTEK. Dalam belajar dapat menaikan derajat dan martabat agar tidak dipandang rendah orang lain. Manfaat belajar itu sendiri akan menghasilkan prestasi, tidak akan susah berteman, akan memiliki pengetahuan lebih disamping itu akan dibutuhkan banyak orang. Sesorang yang terus belajar akan meraih kesuksesan, mendapatkan ketenangan dan meningkatkan kepercayaan dalam diri dan tidak minder, tidak akan ketinggalan jaman dan gaptek. Dengan belajar bisa mendatangkan keberuntungan lainya. Menurut pendapat ahli Suprijono (2011: 7) hasil belajar adalah perubahan perilaku secara keseluruhan bukan 
hanya salah satu aspek potensi kemanusiaan saja. Artinya, hasil pembelajaran yang dikategorikan oleh para pakar pendidikan sebagaimana tersebut di atas tidak dilihat secara fragmentaris atau terpisah, melainkan komprehensif. Menurut pendapat Sam's (2010 : 33) hasil belajar adalah suatu kemampuan yang berupa ketrampilan dan perilaku baru sebagai akibat dari latihan atau pengalaman yang diperoleh. Berdasarkan uraian sebelumnya, dapat disimpulkan bahwa hasil belajar matematika yaitu tingkat penguasaan peserta didik terhadap pelajaran matematika setelah memperoleh pengalaman atau proses pembelajaran dalam kurun waktu tertentu yang akan diperlihatkan dengan menyelesaikan soal-soal sesuai dengan materi yang telah dipelajari dengan penilaian tertentu sebagai alat ukur keberhasilan.

Tujuan dari semua institusi (bila institusi dilihat sebagai kumpulan perjumlahan) adalah sama, namun indikator keberhasilan perjumlahan berbeda dari satu institusi ke institusi lai, karena komitmen dan isi komitmen (sebagaimana tertuang dalam visi dan misi) dari masing-masing institusi berbeda atau tidak sama. Komitmen melahirkan tindakan yang berbeda melahirkan indikator kinerja yang berbeda. Dari perspektif ini ada dua jenis indikator keberhasilan sekolah yaitu indikator umum, dan indikator khusus. Indikator Umum yaitu terbangunya soliditas kohesivitas antara individu dalam lembaga ata institusi dalam mewujudkan visi, misi dan tujuan bersama lembaga atau komunitas. Terbangunya keterbukaan dan kerjasama lintas kelompok, lintas institusi, lintas organisasi, lintas budaya, dan lintas etnik dan lintas agama. Indikator khusus yaitu indikator keberhasilan sekolah perjumpaan secara singkat adalah masing-masing orang mengekspresikan perasaan dan emosinya dengan kalimat atau bahasa yang sesuai secara terbuka dan bertanggungjawab tanpa ada tekanan psikologis ataupun sosial. Masing-masing orang bisa mendengarkan sepenuh hati ekspresi perasaan dan emosinya dan memberikan tanggapan yang tepat secara verbal atau tindakan. Terlaksananya dengan baik dan sukses agendaagenda bersama yang telah menjadi kesepakatan bersama. Penyelesaian konflik dan ketegangan sosial melalui dialog dan kesepahaman bersama terbangunnya sikap tanggap dan respon terhadap berbagai gejala sosial. Berkurangnya konflik dan ketegangan rasial, agama, ekonomi, dan budaya.

Matematika adalah ilmu tentang logika, bilangan, dan keruangan,berikut prosedur operasional yang menghubungkan antara logika, bilangan, dan keruangan (Kamus Besar Bahasa Indonesia). James dan James (Ruseffendi, 1996: 42) dalam kamus matematikanya yang dikutip oleh Ruseffendi menerangkan bahwa matematika adalah ilmu tentang logika mengenai bentuk, susunan, besaran dan konsep-konsep yang saling berhubungan satu sama lainnya dengan jumlah yang banyaknya terbagi kedalam tiga bidang, yaitu aljabar, analisis, dan geometri. Matematika merupakan salah satu komponen dari serangkaian mata pelajaran yang mempunyai peranan penting dalam pendidikan (Sundayana, 2015: 2). Menurut Johnson dan Myklebust (dalam Sam's 2010:11) matematika adalah bahasa simbolis yang fungsi praktisnya untuk mengekspresikan hubunganhubungan kuantitatif dan keruangan sedangkan fungsi teoritisnya adalah untuk memudahkan pemikiran. Dari beberapa pengertian, dapat disimpulkan bahwa matematika merupakan ilmu yang mempelajari tentang logika mengenai bentuk, susunan, besaran, dan konsep-konsep yang berhubungan satu dengan yang lain. Matematika merupakan sebuah ilmu yang dilandasi oleh perkembangan matematika di bidang teori bilangan, aljabar, analistis, teori peluang, dan matematika diskrit dan berhubungan dengan penalaran. Matematika dapat dipelajari dengan kehidupan sehari-hari. Ciri-ciri matematika yaitu memilki aksioma, definis, lemma, teorema, dan melibatkan oprasi bilangan. Kebenaranya terjaga konsistensinya. Konsep bahasan berjenjang dari hal sederhana menuju hal yang lebih kompleks. Membutuhkan penalaran logis. Menekankan pola fikir deduktif, namun dalam proses pembelajaran dan pemahaman terkadang diawali dengan fakta-fakta atau contoh-contoh yang ada dilapangan yang kemudian dibuat kesimpulan matematisnya, induktif-deduktif. Dalam beberapa pokok bahasan dalam diaplikasikan kedalam bidang keilmuan lain dan kehidupan sehari-hari.

Menurut Kasmawati (2017) Dunia pendidikan kita seharusnya mempunyai model atau sistem pakem yang bisa diterapkan pada para anak didik yang berlaku universal dan tidak berubah-ubah, sehingga mampu memberikan aspek kontinuitas dan kepastian pembelajaran. Dengan begitu, pada tataran selanjutnya, prestasi akademik, kemampuan mereka, dan dunia pendidikan secara global akan semakin meningkat secara signifikan. Menurut pendapat Johnson Elaine B (2014: 57) CTL adalah suatu sistem pengajaran yang cocok dengan otak karena menghasilkan makna dengan menghubungkan muatan akademis dengan konteks dari kehidupan sehari hari siswa. Depdiknas dalam (Sumiyati 2011: 14) CTL (Contextual Teaching Learning) adalah konsep belajar yang membantu guru mengkaitkan antara materi pembelajaran yang diajarkan dengan situasi dunia nyata siswa dan mendorong siswa membuat hubungan antara pengetahuan yang dimilkinya dengan penerapanya dalam kehidupan mereka sehari-hari. Berdasarkan pendapat para ahli dapat disimpulkan bahwa (Contextual Teaching Learning) adalah sistem pengajaran yang menghasilkan hubungan muatan akademis dan konteks sehari-hari yang berkaitan dengan dunia nyata. Menurut Zulaiha (2016) CTL merupakan salah satu model pembelajaran yang berasosiasi dengan kurikulum berbasis kompetensi dan cukup relevan untuk diterapkan di sekolah. CTL adalah suatu konsep belajar di mana guru menghadirkan situasi dunia nyata dalam kelas dan mendorong siswa membuat hubungan antara pengetahuan yang dimiliki dengan penerapannya dalam kehidupan, sementara siswa memperoleh pengetahuan sedikit demi sedikit, dan dari proses mengkonstruksi sendiri, sebagai bekal memecahkan masalah dalam kehidupannya. Menurut Hasibuan (2014) Model pembelajaran kontekstual (Contekstual Teaching and Learning) adalah proses pembelajaran yang holistik dan bertujuan membantu siswa 
untuk memahami makna materi ajar dan mengaitkannya dengan konteks kehidupan mereka sehari-hari (konteks pribadi, sosial dan kultural), sehingga siswa memiliki pengetahuan/ keterampilan yang dinamis dan fleksibel untuk mengkonstruksi sendiri secara aktif pemahamannya. Menurut Sabekti (2016) Pembelajaran Contextual Teaching and Learning (CTL) merupakan strategi pembelajaran yang menekankan pada proses keterlibatan peserta didik untuk mendapatkan dan menemukan antara materi yang akan dipelajari dengan realita kehidupan nyata mereka, sehingga peserta didik terdorong untuk menerapkan proses pembelajaran tersebut kedalam kehidupan sehari-hari mereka.

Ciri-ciri CTL yaitu adanya kerja sama antar semua pihak. Menekankan pentingnya pemecahan masalah atau problem. Bermuara pada keragaman konteks kehidupan murid yang berbeda beda. Saling menunjang. Menyenangkan tidak membosankan. Belajar dengan bergairah. Pembelajaran terintregasi. Menggunakan berbagai sumber, murid aktif, sharing dengan teman, murid kritis, guru kreatif, dinding kelas penuh dengan hasil karya murid peta peta, gambar artikel, humor dan tujuan pendekatan CTL. Menurut pendapat Sumiati (2011: 14) penerapan pembelajaran kontekstual dikelas melibatkan tujuh utama pembelajaran efektif yaitu:

a) Kontruktivisme (contructivism) Pengetahuan dibangun oleh manusia sedikit demi sedikit, yang hasilnya diperluas melalui konteks yang terbatas. Pengetahuan bukan seperangkat fakta-fakta, konsep, yang siap untuk diambil dan diingat. Manusia harus mengkontruksi pengetahuan itu dan memberi makna melalui pengalaman nyata. Siswa harus menemukan dan mentrasformasikan suatu informasi kompleks ke situasi lain, dan apabila dikehendaki informasi itu menjadi milik mereka sendiri.

b) Menemukan (inquiry) Artinya dalam pembelajaran kontekstual harus penemuan suatu konsep atau pengetahuan baru dari proses yang dilakukan sendiri oleh siswa.

c) Bertanya (questioning) Dalam pembelajaran harus muncul banyak pertanyaan untuk menggiring siswa dalam menemukan konsep baru

d) Masyarakat Belajar (learning community) Dalam pembelajaran kontekstual harus dapat diciptakan masyarakat belajar, siswa belajar dalam bentuk kelompok untuk melakukan kerja sama.

e) Permodelan (modeling) Pembelajaran ketrampilan tertentu ada model yang ditiru. Berupa cara mengoperasikan sesuatu, guru bukan satu-satunya model. Model dapat dirancang dengan melibatkan siswa. Model dapat didatangkan dari luar, model dijadikan media dalam pembelajaran tersebut, khususnya bidang keterampilan.

f) Refleksi (reflection) Artinya bahwa konsep/ pengetahuan yang telah ditemukan dapat direfleksikan (ke belakang maupun ke depan) agar memiliki makna dalam kehidupan siswa.

g) Penilaian yang sebenarnya (authentik assessment) Pembelajaran kontekstual harus berdasarkan kenyataan yang ada (proses dan hasil) melalui berbagai alat dan jenis penilaian.

Pendekatan Kontekstual disebut juga Contextual Teaching Learning (CTL), tujuan dari penerapan dan pendekatan Pembelajaran Kontekstual adalah untuk meningkatkan prestasi belajar siswa melalui peningkatan pemahaman makna materi pelajaran yang dipelajari dengan mengaitkan materi yang diajarkan dengan konteks kehidupan siswa sehari-hari (konteks pribadi, sosial, kultural, dan sebagainya). Dengan demikian siswa memiliki pengetahuan, sikap, dan keterampilan yang secara fleksibel dapat diterapkan dari satu masalah/konteks ke masalah lainnya. Landasan berpikir yang dipergunakan dalam pembelajaran kontekstual, yaitu bahwa pengetahuan dibangun oleh manusia sedikit demi sedikit yang hasilnya diperluas melalui konteks yang terbatas. Siswa dibiasakan untuk memecahkan masalah, menemukan sesuatu yang berguna bagi dirinya, sedangkan guru memfasilitasi proses tersebut dengan: (a) Menjadikan pengetahuan bermakna dan relevan. (b) Memberi kesempatan pada siswa menemukan dan menerapkan ide sendiri. Model pembelajaran CTL memiliki beberapa tujuan diantaranya yaitu: memotifasi siswa untuk memahami makna materi pelajaran yang dipelajarinya dengan mengkaitkan materi tersebut dengan konteks kehidupan mereka sehari-hari sehingga siswa memilki pengetahuan atau ketrampilan yang secara refleksi dapat diterapkan dari permasalahan kepermasalan lainya. Model pembelajaran ini bertujuan agar dalam belajar itu tidak hanya sekedar menghafal tetapi perlu dengan adanya pemahaman. Model pembelajaran ini menekankan pada pengembangan minat pengalaman siswa; Melatih siswa agar dapat berpikir kritis dan terampil dalam memproses pengetahuan agar dapat menemukan dan menciptakan sesuatu yang bermanfaat bagi dirinya sendiri dan orang lain; Agar pembelajaran lebih produktif dan bermakna; Untuk mengajak anak pada suatu aktivitas yang mengkaitkan materi akademik dengan konteks kehidupan sehari-hari; Agar siswa secara individu dapat menemukan dan mentrasfer informasi-informasi komplek dan siswa dapat menjadikan informasi itu miliknya sendiri.

Menurut pendapat Sumiati (2011: 14) penerapan pembelajaran kontekstual dikelas melibatkan tujuh utama pembelajaran efektif yaitu:

a) Kontruktivisme (contructivism) Pengetahuan dibangun oleh manusia sedikit demi sedikit, yang hasilnya diperluas melalui konteks yang terbatas. Pengetahuan bukan seperangkat fakta-fakta, konsep, yang siap untuk diambil dan diingat. Manusia harus mengkontruksi pengetahuan itu dan memberi makna melalui pengalaman nyata. Siswa harus menemukan dan mentrasformasikan suatu informasi kompleks ke situasi lain, dan apabila dikehendaki informasi itu menjadi milik mereka sendiri. 
b) Menemukan (inquiry) Artinya dalam pembelajaran kontekstual harus penemuan suatu konsep atau pengetahuan baru dari proses yang dilakukan sendiri oleh siswa.

c) Bertanya (questioning) Dalam pembelajaran harus muncul banyak pertanyaan untuk menggiring siswa dalam menemukan konsep baru

d) Masyarakat Belajar (learning community) Dalam pembelajaran kontekstual harus dapat diciptakan masyarakat belajar, siswa belajar dalam bentuk kelompok untuk melakukan kerja sama.

e) Permodelan (modeling) Pembelajaran ketrampilan tertentu ada model yang ditiru. Berupa cara mengoperasikan sesuatu, guru bukan satu-satunya model. Model dapat dirancang dengan melibatkan siswa. Model dapat didatangkan dari luar, model dijadikan media dalam pembelajaran tersebut, khususnya bidang keterampilan.

f) Refleksi (reflection) Artinya bahwa konsep/ pengetahuan yang telah ditemukan dapat direfleksikan (ke belakang maupun ke depan) agar memiliki makna dalam kehidupan siswa.

g) Penilaian yang sebenarnya (authentik assessment) Pembelajaran kontekstual harus berdasarkan kenyataan yang ada (proses dan hasil) melalui berbagai alat dan jenis penilaian.

Prinsip dasar pembelajaran kontekstual adalah agar siswa dapat mengembangkan cara belajarnya sendiri dan selalu mengaitkan dengan apa yang telah diketahui dan apa yang ada dimasyarakat, yaitu aplikasi dan konsep yang dipelajari. Adapun secara terperinci prinsip pembelajaran kontekstual sebagai berikut:

a) Menekankan pada pemecahan masalah.

b) Mengenal kegiatan mengajar terjadi pada berbagai konteks seperti rumah, masyarakat, dan tempat kerja.

c) Mengajar siswa untuk memantau dan mengarahkan belajarnya sehingga menjadi pembelajaran yang aktif dan terkendali.

d) Menekankan pembelajaran dalam kontekstual kehidupan siswa.

e) Mendorong siswa belajar dari satu dengan yang lainya dan belajar bersama-sama.

f) Menggunakan penilaian otentik.

Pembelajaran kontekstual membantu siswa dalam 3 hal yaitu:

1. Pengetahuan, yaitu apa yang ada dipikiranya membentuk konsep, definisi, teori, dan fakta.

2. Kompetensi atau ketrampilan, yaitu kemampuan yang dimiliki untuk bertindak atau sesuatu yang dapat dilakukan.

3. Pemahaman kontekstual, yaitu mengetahui waktu dan cara bagaimana menggunakan pengetahuan dan keahlian dalam situasi kehidupan nyata.

Kemampuan prasyarat yang harus dikuasai siswa dalam oprasi penjumlahan pecahan adalah penguasaan konsep nilai pecahan, pecahan senilai, dan penjumlahan bilangan bulat (Mutijah 2009 : 98). Matematika sekolah mengandung pengertian bahwa matematika dan pola pikirnya disesuaikan dengan proses kemampuan siswa. Meskipun matematika sekolah mempunyai objek yang abstrak,namun pengajarannya dapat dimulai dari objek kongkrit, bidang kajian inti matematika sekolah dasar mencakup bilangan, geometri dan pengukuran, dan pengolahan data. Adapun cakupan materi matematika kelas IV semester genap sebagai materi dalam penelitian ini adalah Operasi Hitung Pecahan yang meliputi:

a) Melakukan operasi penjumlahan bentuk pecahan berpenyebut sama.

b) Melakukan operasi pengurangan bentuk pecahan berpenyebut sama.

Hasil belajar Matematika pada materi operasi hitung penjumlahan pecahan adalah hasil yang peroleh siswa setelah melaksanakan tes tentang materi operasi hitung penjumlahan pecahan yang dilaksanakan setelah siswa mengikuti proses pembelajaran pada materi operasi hitung penjumlahan pecahan. Evaluasi dilaksanakan secara tertulis dengan bentuk soal objektif. Hasil belajar ini dapat dijadikan salah satu indikator berhasil tidaknya sebuah pembelajaran. Di samping itu, proses pembelajaran juga memegang peranan penting dalam keberhasilan sebuah pembelajaran.

Berdasarkan ulangan harian mata pelajaran Matematika materi operasi hitung pecahan menunjukkan bahwa dari 28 siswa, hanya 10 siswa yang memperoleh nilai di atas KKM ( $\geq 65)$ artinya hanya $36 \%$ yang tuntas, dan selebihnya 18 siswa belum mencapai KKM artinya $64 \%$ belum tuntas nilai $(\leq 65)$. Nilai rata-rata kelas 63,57. Siswa yang belum tuntas disebabkan pengelolaan kelas yang kurang dikuasai oleh guru, Rendahnya hasil belajar disebabkan pemahaman siswa terhadap konsep-konsep dalam materi bilangan pecahan, kurangnya minat anak dalam mempelajari matematika, Guru belum menggunakan alat peraga/media dalam pembelajaran, metode yang digunakan berupa ceramah yang bersifat membosankan.

\section{Metode}

Tempat penelitian ini dilakukan di SDN Wedarijaksa 01 Kelas IV Kecamatan Wedarijaksa, Kabupaten Pati, dengan jumlah siswa 28 orang, terdiri dari laki-laki 11 orang dan perempuan 17 orang. Kegiatan Penelitian ini dilaksanakan pada bulan Januari sampai dengan bulan Maret 2019. Hal ini dibagi siklus 1 pada hari Sabtu tanggal 23 Februari 2019 dan siklus 2 hari Rabu tanggal 27 Februari 2019. Data penelitian yang dikumpulkan 
adalah (1) Perangkat pembelajaran yang dibuat guru;(2) Buku Sumber; (3) daftar Nilai; (4) Hasil observasi; (5) Masukan dari observer yang dilakukan selama penelitian. Teknik yang digunakan untuk mengumpulkan data adalah tes, tugas dan pengamatan/observasi dan dokumentasi. Alat untuk mengumpulkan data tergantung pada teknik yang digunakan. Butir soal alat untuk teknik tes, pedoman dan lembar observasi untuk teknik non tes/pengamatan, kamera digital untuk teknik dokumentasi. Data kuantitatif dianalisis menggunakan diskripsi komparatif yaitu dengan membandingkan hasil mulai siklus awal, siklus 1 dan siklus 2. Data kualitatif menggunakan diskripsi kualitatif berdasarkan hasil observasi dan refleksi dari tiap-tiap siklus. Pendekatan pembelajaran CTL (Contextual Teaching And Learning) dikatakan efektif untuk meningkatkan hasil belajar matematika jika siswa dapat mencapai KKM yang telah ditetapkan yaitu 65 dan persentase tuntas klasikal sekurang-kurangnya $75 \%$ (minimal $75 \%$ siswa yang memperoleh skor $\geq 65$ ).

Pelaksanakan dalam penelitian ini menggunakan metode Penelitian Tindakan Kelas yang masing-masing siklus terdiri dari 4 tahap yaitu:

\section{Siklus I}

a. Perencanaan (Planning)

Yang meliputi: (1) menyusun promes dan silabus, (2) menyusun kisi-kisi soal, (3) menyusun skenario pembelajaran kooperatif (RPP), (4) membuat LKS pembelajaran dengan teknik pemodelan, (5) menyiapkan media pembelajaran, (6) menyusun soal ulangan harian, (7) menyiapkan instrumen observasi.

b. Pelaksanaan dan Observasi

Yang meliputi langkah-langkah: (1) membuat kelompok belajar yang terdiri dari 6-8 siswa, (2) melaksanakan KBM dengan teknik pemodelan, (3) mengerjakan ulangan harian. Observasi pelaksanaan pembelajaran dilakukan secara kolaborasi dengan teman sejawat dengan menggunakan alat-alat monitoring berupa instrumen yang telah direncanakan. Pada akhir siklus I guru mengadakan wawancara dengan siswa. Validasi hasil dilakukan dengan triangulasi dari siswa, guru dan teman sejawat.

c. Refleksi (Reflecting)

Yang meliputi menganalisa data kuantitatif dan kualitatif dari hasil observasi dengan instrumen yang telah ada. Hasil analisa digunakan untuk melihat hasil tindakan baik positif maupun negatif dan untuk menentukan tindak lanjut siklus berikutnya. Refleksi dilakukan dengan menggunakan analisis deskriptif komparatif yaitu membandingkan hasil observasi kondisi awal dengan hasil observasi pada siklus I.

2. Siklus II

a. Perencanaan (Planning)

Pada tahap ini meliputi: (1) identifikasi permasalahan siklus I dan rencana perbaikan, (2) menyusun RPP LKS Pembelajaran penjumlahan pecahan., (3) identifikasi masalah untuk diskusi dilaksanakan sama dengan siklus I. Namun perlu upaya untuk lebih meningkatkan aktivitas siswa dan menggali masalah dengan diri siswa maupun dari guru, (4) menyusun ulangan.

b. Pelaksanaan (Acting)

Proses pembelajaran siklus ini sama dengan siklus I dan merupakan perbaikan dari siklus I dan semua kelemahan-kelemahan yang muncul selama pelaksanaan siklus I diperbaiki pada siklus II ini. Peraikan ini ditujukan untuk menumuhkan aktivitas siswa dalam belajar, pada awal siklus II siswa masih perlu dijelaskan tentang pembelajaran penjumlahan pecahan.

c. Pengumpulan Data (Observasi)

Pada tahap ini sama dengan siklus I data yang dipandang penting seperti data kemajuan hasil belajar dan data aktivitas belajar yang dipantau lewat lembar observasi kelas, hasil pengamatan siswa dan hasil pekerjaan siswa.

d. Refleksi (Reflecting)

Refleksi pada siklus II ini difokuskan pada pengalaman yang diperoleh dari siklus I, menilai kembali sasaran perbaikan yang ditetapkan. Refleksi dilakukan dengan menggunakan analisis deskriptif komparatif yaitu dengan membandingkan hasil observasi siklus I dengan hasil oservasi pada siklus II.

\section{A. Pertemuan pada Siklus 0/Keadan Awal/Pra Siklus}

\section{Hasil dan Pembahasan}

1. Nilai rata - rata pada siklus 0, tentang operasi hitung penjumlahan pecahan adalah, 63,57 siswa, 18 siswa belum tuntas dan 10 siswa tuntas

2. Berdasar hasil pengamatan siklus 0 terhadap kemampuan siswa dalam standar kompetensi operasi hitung penjumlahan pecahan, peneliti mengupayakan adanya tindakan kelas untuk tercapainya tujuan pembelajaran dan mencapai Kriteria Ketuntasan Minimal (KKM) sebesar 65,00.

B. Pertemuan pada Siklus I

1. Nilai rata-rata pos tes siklus I dalam tentang operasi hitung penjumlahan pecahan adalah 71,79 dari 28 siswa, 8 siswa belum tuntas dan 20 siswa tuntas. 
2. Hasil tersebut menunjukkan bahwa sudah ada perkembangan atau peningkatan kemampuan siswa dalam mempelajari kompetensi dasar operasi hitung penjumlahan pecahan.

C. Pertemuan pada Siklus II

1. Nilai rata - rata pos tes siklus II adalah 81,50 , dari 28 siswa semua tuntas.

2. Hasil tersebut menunjukkan siswa siswa sudah mempunyai kemampuan untuk menguasai kompetensi dasar operasi hitung penjumlahan pecahan dengan ditandai nilai rata-rata pos tes yang sudah diatas Kriteria Ketuntasan Minimal (KKM) dan sudah menunjukkan dengan prosentase siswa yang cukup tinggi.

3. Hal di atas dapat ditunjukkan pada Tabel 1 dan Gambar 1 di bawah ini.

Tabel 1. Hasil Belajar Siswa

\begin{tabular}{|c|c|c|c|c|c|c|}
\hline \multirow{2}{*}{ Hasil Belajar } & \multicolumn{2}{|c|}{ Pra Siklus } & \multicolumn{2}{|c|}{ Siklus I } & \multicolumn{2}{|c|}{ Siklus II } \\
\hline & Jml Siswa & $\%$ & Jml Siswa & $\%$ & Jml Siswa & $\%$ \\
\hline Skor $<65$ & 18 & 64 & 8 & 29 & - & - \\
\hline Skor $\geq 65$ & 10 & 36 & 20 & 71 & 28 & 100 \\
\hline Tuntas belajar & 10 & 36 & 20 & 71 & 28 & 100 \\
\hline Tidak tuntas belajar & 18 & 64 & 8 & 29 & - & - \\
\hline Nilai rata-rata & \multicolumn{2}{|c|}{63,57} & \multicolumn{2}{|c|}{71,79} & \multicolumn{2}{|c|}{$\mathbf{8 1 , 5 0}$} \\
\hline
\end{tabular}

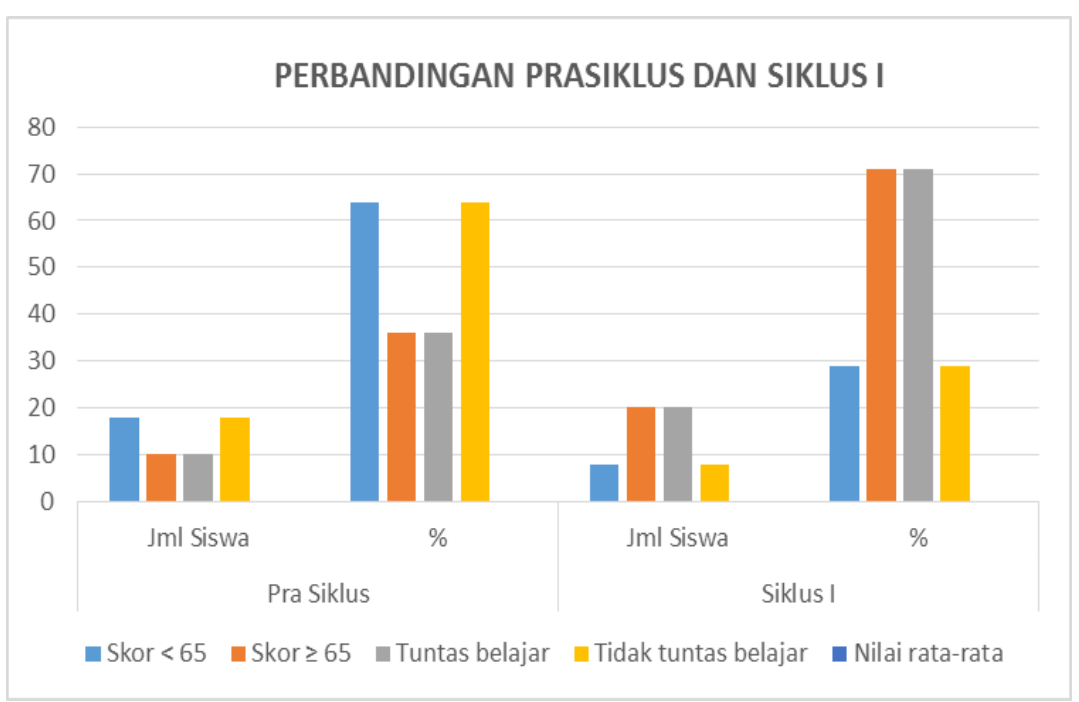

Gambar 1. Perbandingan Prasiklus dan Siklus 1

Pada tahap awal Penelitian Tindakan Kelas, peneliti mengadakan pengamatan awal terhadap aktifitas siswa. Guru mengamati pada proses pembelajaran kompetensi dasar operasi hitung penjumlahan pecahan ternyata kemampuan siswa masih kurang, atau tidak mencapai KKM, dibuktikan hanya memperoleh nilai ratarata 63,57. Maka selanjutnya dilakukan tindakan, dengan melaksanakan Penelitian Tindakan Kelas.

Pada siklus I, setelah siswa pelaksanaan tindakan siswa memperoleh nilai rata-rata 71,79 artinya menunjukkan bahwa sudah ada perkembangan atau peningkatan kemampuan siswa dalam mempelajari kompetensi dasar operasi hitung penjumlahan pecahan, dibandingkan sebelumnya walaupun masih belum mencapai KKM.

Pada siklus II setelah dilakukan tindakan menunjukkan bahwa siswa mendapatkan nilai rata-rata 81,50 hal ini membuktikan bahwa siswa sudah mempunyai kemampuan untuk menguasai kompetensi dasar operasi hitung penjumlahan pecahan dengan ditandai nilai tersebut sudah di atas Kriteria Ketuntasan Minimal (KKM) yang sudah ditetapkan dalam kurikulum yaitu 65,00. Dengan demikian dapat dikatakan kemampuan menguasai kompetensi dasar operasi hitung penjumlahan pecahan sudah menunjukkan kemajuan yang cukup tinggi.

\section{Simpulan}

Berdasarkan analisis pembahasan yang dikemukakan di atas setelah diadakan Penelitian Tindakan Kelas, dapat diambil simpulan bahwa dengan cara menerapkan langkah-langkah pendekatan CTL (contextual teaching and learning pada pembelajaran matematika siswa kelas IV SDN Wedarijaksa 01 dalam operasi hitung penjumlahan pecahan hasil belajar siswa dapat meningkat. Langkah-langkah pendekatan CTL (contextual teaching and learning dapat merangsang daya pikir dan ketekunan serta antusias siswa dalam mengerjakan soal 
hitung pecahan serta melatih siswa berpikir runtut dan sistematis, serta meningkatnya hasil kinerja guru dalam kompetensi profesional guru.

Dengan menggunakan pendekatan CTL (Contextual Teaching and Learning) memudahkan siswa memahami permasalahan pada materi operasi hitung penjumlahan pecahan yang masih abstrak. Guru diharapkan agar lebih sering menggunakan teknik pemodelan dan memberdayakan alat peraga, juga disertai LKS agar pembelajaran dapat lebih bermakna baik bagi siswa maupun bagi guru sebagai pendidik.

\section{Daftar Pustaka}

Hasibuan, M. Idrus. 2014. Model Pembelajaran CTL (Contextual Teaching and Learning). Logaritma Vol. II, No.01 Hal. 1-12. Tersedia $\quad$ Pada: padangsidimpuan.ac.id/index.php/LGR/article/download/214/195

James, And James. 1976."Hakikat Matematika Dan Pembelajarnya Di SD". https://www.google.com/search?q=depdikbud+tentang+hakikat+matematika+tahun+1993+hal+198\&spel l=1\&sa=X\&ved=0ahUKEwjxr_Wm6s_bAhWafSsKHQivDEkQBQgkKAA\&biw=1366\&bih=631. Diakses pada tanggal 13 juni 2018 pukul 11.51 .

Johnson, Elaine B. 2014. "Contextual Teaching Dan Learning". Bandung: Kaifa.

Kasmawati, Nur Khalisah Latuconsina, Andi Ika Prasati Abrar. 2017. Pengaruh Model Pembelajaran Contextual Teaching and Learning (CTL) terhadap Hasil Belajar. Jurnal Pendidikan Fisika Vol. 5 No. 2, Hal. 70-75. Tersedia Pada: http://journal.uin-alauddin.ac.id/indeks.php/PendidikanFisika.

Nara, Hartini dan Siregar. 2014. "Teori Belajar Dan Pembelajaran” . Bogor: Ghalia Indonesia.

Rohmad, Muhammad Ali. 2015. "Pengelolaan Kelas Bekal Calon Guru Berkelas". Yogyakarta : KAUKABA DIPANTARA.

Sabekti, Ardi Widhia, R. Dinda Rahma Andyani Juniar. 2016. Contextual Teaching and Learning (CTL) untuk Membangun Pembelajaran Bermakna pada Kimia. Jurnal Zarah, Vol. 4, No. 1, Hal 25-33. Tersedia Pada: https://ojs.umrah.ac.id/index.php/zarah/article/view/170/160.

Sam’s, Rosma Hartiny. 2010. “Model Penelitian Tindakan Kelas”. Yogyakarta: Teras.

Sugandi Achmad dan Haryanto, 2005,Teori Pembelajaran, Semarang : UPT MKK Unnes.

Sugiyono. 2016. "Metode Penelitian Pendidikan". Bandung: ALFABETA.

Sulastri. 2013. "Jurnal Pendidikan Widyatama”. LPMP Jawa Tengah. Volum 1, no 3, juli 2013.

Sumiyati dan Asra. 2011. "Metode Pembelajaran". Bandung: CV WACANA PRIMA.

Sundayana, Rostina. 2015. "Media Dan Alat Peraga dalam Pembelajaran Matematika”. Bandung: Alfabeta. Suprijono, Agus. 2011. “Cooperative Learning Teori dan Aplikasi Paikem”. Yogyakarta: Pustaka Belajar.

Zulaiha, Siti. 2016. Pendekatan Contextual Teaching And Learning (CTL) Dan Implementasinya Dalam Rencana Pembelajaran PAI MI. Jurnal Pendidikan Islam vol. 1, no 01, Hal. 41-60. Tersedia Pada: http://journal.staincurup.ac.id/index.php/belajea/article/view/84. 